\title{
A Study on the Targeted Poverty Alleviation Path of Rural E-commerce in Shaanxi Province
}

\author{
Yan Wang \\ Business School of Xi'an Peihua University, Xi'an, Shaanxi, China
}

Keywords: Rural e-commerce; Targeted poverty alleviation; Development path.

\begin{abstract}
Rural e-commerce is an important way to transform rural agricultural development mode, and it is a platform for farmers to interconnect with consumers. It is also an important carrier of targeted poverty alleviation, and the important channel for farmers to increase their income. It is of great significance for Shaanxi rural areas to cast off poverty and get rich by perfecting rural e-commerce industry chains from the aspects such as network infrastructure construction, rural logistics, financial funding support, construction of pilot bases of poverty alleviation, brand cultivation of agricultural products, and peasant household e-commerce skills training, and exploring the targeted poverty alleviation path of rural e-commerce.
\end{abstract}

\section{Introduction}

In recent years, with the rapid development of Shaanxi agricultural industrialization, many agricultural products with Shaanxi characteristics were confined in the province. Such as Red dates and potatoes in northern Shaanxi, apples, grapes and kiwis in Guanzhong, tea and walnuts in southern Shaanxi. They could not enter the big market and realized the great circulation, which caused the disconnection between the production and sales. There were also some problems like the severe unsalable phenomenon of agricultural products and the increasing production without increasing income. Rural e-commerce is an important way to transform rural agricultural development mode, and it is also an important carrier of targeted poverty alleviation. It is an urgent task to develop Shaanxi rural e-commerce, promote the export of agricultural products, develop modern service industries such as rural logistics and finance, and speed up the transformation and upgrading of traditional industries and the substantial economy.

For implementing documents such as the NO.1 Central Document of 2017, Decision of the CPC Central Committee and State Council on Winning the Battle of Poverty( CCCPC [2015] No. 34), The Guidance of State Council General Office on Accelerating the Development of Rural E-commerce (State Council [2015] No. 78), and further accelerating the development of rural e-commerce, in 2017, the Commerce Department with the Ministry of Finance and the Poverty Relief Office of the State Council continue to conduct comprehensive demonstration work of rural e-commerce. They have set up 19 comprehensive demonstration counties of rural e-commerce in Shaanxi to accelerate the process of e-commerce poverty alleviation and promote the development of rural e-commerce.

\section{The Connotation of the Targeted Poverty Alleviation of Rural E-commerce}

Rural E-commerce. The rural e-commerce platform constructs a well-organized business union by the coordination of intensive rural branch network, the method of digitization and informatization, intensive management, market-oriented operation and the systematic collaboration of different regions and industries. It can effectively reduce the rural commercial cost, expand the rural commercial domain, make the farmers become the biggest profit of the platform, and help the merchants gain new profit growth. With the help of information platforms such as the Internet, rural e-commerce provides online sales, purchase and payment of the products or the service for the 
operators engaged in agriculture. At the same time, the rural e-commerce platform takes agricultural website platforms as the main carrier, organizes relevant elements together through the network.

Targeted Poverty Alleviation of Rural E-commerce. The development of rural e-commerce can effectively solve the problems such as the unsalable condition of agricultural products because of unsymmetrical information, the difficulty in identifying the causes of poverty, and the difficulty of quantification of the poverty alleviation effect. Through the analysis of the large data, e-commerce can establish objects of poverty alleviation, identify the key factors of poverty, create an e-commerce service innovation system, and find way out for poverty alleviation, which is a helpful power for Shaanxi targeted poverty alleviation work. It also provides decision-making support for the government to formulate targeted poverty alleviation plans and strategies, and provides reference for rural economic development in Shaanxi province.

Through e-commerce skills training, market precise docking, policy support, service delivery and other means, the targeted poverty alleviation of rural e-commerce can directly help poor families get profit from e-commerce operation and transaction. Through the local enterprises and organizations engaged in the management of e-commerce, based on pilot bases of e-commerce poverty alleviation, the rural e-commerce builds up the e-commerce oriented industrial chains to help and attract low income families to participation, and realizes their employment and entrepreneurship, so as to achieve the effect of poverty alleviation and wealth achievement.

\section{The Analysis on Path of Targeted Poverty Alleviation of Shaanxi Rural E-commerce}

Through the analysis on the aspects such as network infrastructure construction, rural logistics, financial funding support, construction of pilot bases of poverty alleviation, brand cultivation of agricultural products, and peasant household e-commerce skills training, the paper tries to explore the internal and external path of the development of targeted poverty alleviation of rural e-commerce.

External Poverty Alleviation Support Path. Construction of Network Facilities. To support the poverty alleviation, the government must strengthen the network infrastructure construction, the rural information infrastructure construction and broadband popularization, and improve the quality of network and coverage to make sure that every village can have the broadband. At the same time, the Internet cost of villagers must be reduced through speeding up the broadband network and reduce the cost. The government should also actively promote rural Internet information application, and further deepen cooperation with big e-commerce enterprises, perfect the information service system which focuses on " providing the supply and demand information of agricultural products to the villagers", expand new channels and customers for the agricultural producers, and give full play to the advantages of the good connection between production and sales of rural e-commerce. Moreover, by the support of the development of the big data industry, the government should accelerate the construction of the rural integrated information service platform, the transformation of the rural operating service network and the process of e-commerce of agricultural products trade. What's more, the government can promote rural resources and agricultural products with the aid of new media such as Weibo and Wechat. At the same time, the informatization integrated service platform with electronic party affairs, village affairs, business and farm affairs can be set to help introduce the Internet thinking into the country.

Rural Logistics Distribution. In the construction of agricultural products logistics, the government departments should base on local actual e-commerce development, guide the local to build corresponding logistics service centers step by step, ensure the long-term development of e-commerce enterprises. The agricultural products logistics centers is an important mode of the transportation of product sale. Therefore, in terms of planning and construction, the centers should cooperate with the development of e-commerce. The government departments should strengthen the rural infrastructure construction, vigorously implement the maintenance and reconstruction of the national, the provincial and the country highway and the construction plan of village roads. They should also promote the rigiditilation of new rural roads, strengthen the reinforcement and transformation of the villages' roads and bridges in order to thoroughly improve rural traffic environment. In addition, they need to take the rural e-commerce village-level operation network as 
the support to guide the postal and express delivery operations to rural areas. Through the village-level integrated service stations, the e-commerce distribution sites of the village agricultural products are established, which makes further improvement on the rural logistics distribution capacity and realizes the seamless connection of the logistics network among the counties, towns and villages.

Financial Support. The government departments should bring the e-commerce poverty alleviation into the support scope of micro-credit. The relevant departments can offer free mortgage, free guarantee, micro-credit support, and interest subsidy in full amount according to the base rate to the low income families that engage in internet sales and also to the enterprises and online stores which help those poor families do sales on the internet with an obvious effect. The rural credit cooperatives and rural commercial Banks are encouraged to set up service sites in poverty-stricken townships, and establish financial service agencies in villages to improve the financial services conditions of rural online stores such as payment, settlement, etc. Rural financial institutions are given preferential treatment in order to enable financial enterprises to have confidence in rural e-commerce enterprises and individuals. The government will vigorously promote the construction of rural e-commerce public service centers in various counties and villages in Shaanxi, and expand the development of lower-level sites. The integration of e-commerce and traditional agriculture is also promoted. The development of e-commerce with the agricultural product supply chain of purchasing, producing and selling based on the industrial layout is encouraged .

Internal Poverty Alleviation Support Path. The Construction of Poverty Alleviation Bases of E-commerce. The establishment of e-commerce demonstration comprehensive pilot bases are actively organized to carry forward the construction of poverty alleviation bases of e-commerce. The pilot sites will spread in counties, towns and villages. There will be a fund bonus for the places where the e-commerce poverty alleviation goes well. Also the relevant project application of these places such as the application of the nursery finance in science and technology can be taken into consideration in the first place. The aim of setting up poverty alleviation pilot sites is to cultivate a group of rural e-commerce leading enterprises and entrepreneurial leaders and fasten the coverage of e-commerce to villages, especially the poor areas.

The Brand Cultivation of Agricultural Products. Developing characteristic industries and cultivating characteristic brands energetically according to the principle of "one county, one industry" and "one village one variety". Supporting agricultural products' application of certification such as "landmark protection", "green", "organic" and "pollution-free" and other qualifications. Strengthening the brand building of featured products in poverty-stricken areas and improving product quality, value and popularity. The agricultural products catalog library of e-commerce poverty alleviation is necessary to be established, which means carrying out investigation and census of the planting scale, the production output, the quality and characteristics of the high-quality agricultural products with characteristics, determining the leading brand and compiling the catalogue of the dominant products. Guiding and supporting the poor villages to at least develop a leading enterprise of producing, processing, packaging, selling characteristic agriculture products. And then conducting certification, management and support. For local agriculture branding, the key problem is to formulate a unified standard of quality and packaging, and create agricultural products with distinctive regional characteristics. Brand construction has created the precondition for the profit growth of agricultural products. Building e-commerce sales system, carrying out the segmentation of agricultural products, which can be divided into varieties of fruit, dried fruit, Chinese herbal medicine and traditional food. The varieties such as handicraft and traditional cloth art can be incorporated into the e-sales resources. Agricultural products should have obvious regional characteristics. It is necessary to build the selling advantages of the agricultural products, and realize differentiation, specialization and standardization of local characteristics. Relying on the advantage of the unique geographical position to develop characteristic agricultural product brands.

The Skill Training of E-commerce. At present, the basic level of farmers' basic culture is very low. In Shaanxi, farmers know very little about the network. Therefore, relevant departments should assign the e-commerce experts to carry out the guidance of learning e-commerce skills, teach the 
network knowledge and e-commerce concept, let them learn to use the Internet. The experts can also introduce the e-commerce development and its development in rural areas. At the same time, they should teach farmers how to operate and run business in e-commerce platforms, and how to carry out Internet commerce and marketing. Meanwhile, the relevant government departments should start training and introducing e-commerce talents as soon as possible, and they should attract college students who studied related majors to return home seeking for development, and encourage them to contribute to the development of rural e-commerce. The government should encourage and help these young people realize their dreams by the trend of e-commerce. Also the relevant departments should help enterprises and farmers to sell their products, expand the influence of e-commerce, and achieve a win-win situation through e-commerce platforms.

\section{The Countermeasures and Suggestions for the Targeted Poverty Alleviation of Rural E-commerce in Shaanxi Province}

Precise Identification. The precise identification of poverty-stricken villages and poor people is the first step in the implementation of targeted poverty alleviation. Only after that, the poverty alleviation effect can be improved. The development-oriented poverty alleviation should not only accurately identify the poor, but also accurately identify the target of poverty alleviation. The aim of the identification is to guarantee the poor can become the subject of running the e-commerce directly. To those with certain education background, they can accept training about relevant knowledge and skills of e-commerce. The local government departments can provide them places, fund, products and skill guidance to help them gradually engage in e-commerce jobs or directly run e-stores (stores in Taobao and Wechat). They can gain profit through selling products. It is of great importance to note that skills training for the poor is particularly important. From the training of running an e-store, the customer service training, to the high-level training such as the marketing skills training, the brand management training, from the government-led training to various training held by the e-commerce enterprises or social poverty alleviation organizations, the aim is to make the poor have relevant knowledge and skills, encourage them to participate in the development of local e-commerce, help them gain more business and employment opportunities, and ultimately get rid of poverty.

Precise Assistance. Confirming the poverty alleviation subjects in view of the specific situation of poverty-stricken farmers. To make sure that we actually help the poor and help the real poor, we should make accurate plans, confirm the measures, and try our best on assistance. We should solve the sales problem of agricultural products. Most of the poor households have no ability to run e-commerce, even after being trained for a period of time. Those e-stores selling agricultural products also have problem of lacking innovation, which leads to the limitation of the actual sale. For most of the poor, they need the increasing income more than the skills. In the practice of the poverty alleviation, assistance groups provides the poor the seed, the manure and raising technology and other support, but many of the poor have no confidence in the future sales, leading to a low enthusiasm of planting. Therefore, the precise assistance must ensure the quantity and quality of the supply of agricultural products, and secondly, to achieve certain sales. When assisting them, the assistance groups can teach them the skills of running e-commerce step by step and finally make sure that they can sell products on the Internet independently.

Precise Construction. The local rural cooperative will be built to assist the poor. By joining the cooperative, the poor households can effectively improve their systematism and solve the dispersal problem of agricultural products in the market. In the process of building poverty alleviation, we should give full play to the active role of the rural cooperatives, build a sales system with cooperatives as a bridge, and improve the mechanism of promoting poverty alleviation. Integrating the e-commerce operators, bases and poor households by cooperatives can solve the market risk of individual farmers' production, and it can also ensure the quantity and quality of products produced by poor households. It is conducive to establish the traceability system of agricultural products, produce excellent agricultural products, promote products with geographical characteristics, and continuously improve the additional value of agricultural products, so that more poor households can benefit from it. 
Precise Management. Precision management refers to the need for the government to strengthen the monitoring of poverty-stricken households with targeted poverty alleviation, ensure the effective assistance to poor villages and poor households, and achieve the goal of stabilizing poverty alleviation within the stipulated time. For the precise management towards poverty alleviation bases of rural e-commerce, through the longitudinal collaboration of the industrial chain, the relevant departments can contact customers and farmers in advance to sign production and sales contracts with the e-commerce enterprises to push them adopt characteristic agricultural products in advance. Second, providing seeds and technical support for farmers, effectively reducing production costs and market risks. The rural e-commerce can also actively play its financial advantages and industry advantages, establishing the agricultural e-commerce demonstration base with brand advantages. Through the organization of various agricultural tourism activities and "agricultural products go into the community" activities to extensively attract poor households to participate in the e-commerce of agricultural products and to share the profit. The positive effect of poverty alleviation is the key, so the role of government cannot be ignored. Governments at all levels should implement the relevant support policies to strengthen the operation and supervision. To achieve its impact in poverty alleviation on the basis of the healthy development of promoting the construction of poverty alleviation bases of rural e-commerce.

\section{Acknowledgements}

Project Fund: The special scientific research planned project of the Department of Education of Shaanxi in 2007: A Study on the Targeted Poverty Alleviation Path of Rural E-commerce in Shaanxi Province (Project Number: 17JK1047). The university-level research project of Xi'an Peihua University: Research on the Innovative Development Path of Shaanxi Knowledge-intensive Service Industry (Project Number: PHKT17008) the stage research achievement.

\section{References}

[1]Nan Zhang. Study on the E-commerce Mode of Agricultural and Commercial Products in Heilongjiang Province [J]. Technology and Industry Across the Straits, 2016(12): 75-77.

[2] Tao Hong. Research on the Development of E-commerce of Agricultural Products - Research on the Innovation of Agricultural Products [J]. Rural Finance Ressarch, 2015(08): 6-12.

[3] Yong-Wei Ji. Research on Search Marketing in Electric Business Mode [J]. China Collective Economy, 2016(19): 54-55.

[4] He-Fei Ma.The Longnan Mode of Targeted Poverty Alleviation of E-commerce [J]. Rule by Law and the Society, 2016(10): 215-217.

[5] Zuo-Ben Zhang. Give Full Play to the Advantages of E-commerce to Implement Targeted Poverty Alleviation-The Investigation Paper of Rural E-commerce in Wugong County of Shaanxi [J]. Agriculture Informatization, 2016(01): 62-65.

[6] Dan-Qing Li. The E-commerce Poverty Alleviation under "Internet +": Choke points, Advantages, Orientation --A Realistic Study on the Poverty Alleviation in Rural Electricity [J].Contemporary Economy, 2016(4): 27-28. 